\title{
Coordinate Expression of c-fos and jun B Is Induced in the Rat Striatum by Cocaine
}

\author{
Rosario Moratalla, ${ }^{1}$ Elizabeth A. Vickers, ${ }^{2}$ Harold A. Robertson, ${ }^{3}$ Brent H. Cochran, ${ }^{2}$ and Ann M. Graybiel ${ }^{1}$ \\ 'Department of Brain and Cognitive Sciences and ${ }^{2}$ Center for Cancer Research, Massachusetts Institute of Technology, \\ Cambridge, Massachusetts 02139 and ${ }^{3}$ Department of Pharmacology, Dalhousie University, Halifax, Nova Scotia, Canada, \\ $\mathrm{B} 3 \mathrm{H} 4 \mathrm{H} 7$
}

\begin{abstract}
In cells in culture, specific stimuli induce selective patterns of immediate-early gene induction. In the present study, we tested for such selectivity of stimulated gene expression by monitoring the expression of fos/jun gene mRNAs in the striatum in rats treated in vivo with the indirect dopamine agonist cocaine. We found by Northern blot and in situ hybridization analysis that cocaine induces the coordinate expression of c-fos and jun $B$ mRNAs in neurons of the rat's striatum. By contrast, another immediate-early gene of the leucine-zipper family, c-jun, was not induced in striatal neurons by cocaine at any time tested from 1 to $24 \mathrm{hr}$ after treatment. With the same probe, we could detect the induction of c-jun mRNA (as well as that of $c$-fos and jun B mRNAs) in the hippocampus following administration of pentylenetetrazol. The induction of expression of $c-$ fos and jun $B$ was rapid and transient, with peak expression occurring at approximately $1 \mathrm{hr}$ after cocaine administration, and the induction of the two genes was in similar striatal sites. These results establish that differential patterns of expression of fos/jun genes occur in striatal neurons following exposure to cocaine, a potent psychomotor stimulant. We suggest that these tissue-specific patterns of gene expression may contribute to the response specificity of striatal neurons to stimulation by monoamines including dopamine.
\end{abstract}

[Key words: striatum, dopamine, cocaine, immediate-early genes, c-fos, jun B]

Studies of transcription factor activation in cell culture have established a high degree of combinatorial complexity in the acute genomic response of cells to stimuli ranging from growth factors to membrane depolarization agents (Sheng and Greenberg, 1990). An example is the activation of genes of the AP-1 transcription factor complex, which is composed of multiple members of the fos/jun immediate-early gene family (Cochran et al., 1984; Greenberg and Ziff, 1984; Muller et al., 1984; Boh-

\footnotetext{
Received Jan. 23, 1992; revised May 27, 1992; accepted July 14, 1992.

This work was funded by Javits Award NS25529, The Human Frontier Science Program, the United Parkinson Foundation, and Biomedical Research Support Grant NIH-2S07-RR07047-26. We thank Ms. Amelia Rosales and Mr. Glenn Holm for their expert technical support; Mr. H. F. Hall, who is responsible for the photography; and Ms. Celia Schneider for word processing.

Correspondence should be addressed to Dr. Ann M. Graybiel, Massachusetts Institute of Technology, Department of Brain and Cognitive Sciences, E25-618, 45 Carleton Street, Cambridge, MA 02139.

Copyright (C) 1993 Society for Neuroscience $0270-6474 / 93 / 130423-11 \$ 05.00 / 0$
}

mann et al., 1987; Distel et al., 1987; Lee et al., 1987; Angel et al., 1988a; Chiu et al., 1988; Curran and Franza, 1988; Rauscher et al., 1988b; Vinson et al., 1989; Abate et al., 1990a,b). Members of this family share leucine-zipper dimerization domains with basic DNA binding motifs, and the protein products of these genes can act in combination by forming heterodimers and homodimers (Bohmann et al., 1987; Chiu et al., 1988; Halazometis ct al., 1988; Kourazides and Ziff, 1988; Landschulz et al., 1988; Nakabeppu et al., 1988; Rauscher et al., 1988a,b; Sassone-Corsi et al., 1988; O’Shea et al., 1989; Vinson et al., 1989). These DNA binding proteins can regulate transcription negatively as well as positively (Bohmann et al., 1987; Chiu et al., 1988, 1989; Schutte et al., 1989; Lamph et al., 1990), have different kinetics on induction (Sonnenberg et al, 1989a; Kovary and Bravo, 1991), and can differ markedly in their responses to different signaling agents (Bartel et al., 1989; de Groot et al., 1991).

Investigations of immediate-early gene regulation in the CNS are just beginning to take account of such complexities. For example, in the hippocampal seizure model, probes for immediate-early genes of the fos/jun (leucine-zipper) family and members of the $N G F I$-A (zinc finger) family are coinduced by intense electrical or pharmacological stimulation (Dragunow and Robertson, 1988; Saffen et al., 1988; Cole et al., 1989; Sonnenberg et al., 1989a; Watson and Milbrandt, 1989). By contrast, tetanic stimulation leading to long-term potentiation (LTP) readily induces only a subset of these immediate-early genes (NGFI-A and, less consistently, jun B) (White and Gall, 1987; Wisden et al., 1990). These different responses may be implicated in the selective regulation of other genes. Following induction of LTP, elevated transcription of neuropeptide (Gall et al., 1990) and of NGF (Gall et al., 1991) has been reported as late responses to stimuli activating immediate-early genes. AP-1like sites, binding sites for Fos/Jun dimers, have been identified in both proenkephalin (Sonnenberg et al., 1989b) and prodynorphin (Naranjo et al., 1991).

In the experiments reported here, we tested for differential in vivo activation of fos/jun genes in the striatum, the principal target of the dopamine-containing nigrostriatal tract. We and others have shown that indirect dopamine agonists, including the psychomotor drugs cocaine and amphetamine, induce rapid D1-like dopamine receptor-mediated increases of c-fos mRNA and Fos-like proteins in the striatum (Graybiel et al., 1990; Young et al., 1991). The patterns of induction are anatomically selective, suggesting that stimulant drugs induce Fos-like transcription factors in particular subsets of striatal neurons having 


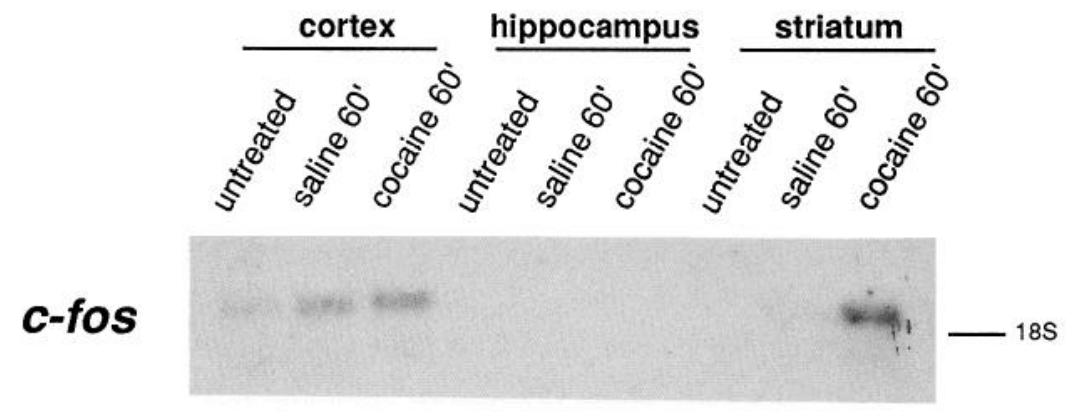

Figure 1. Northern blot analysis demonstrating induction of $\mathrm{c}-$ fos and jun $B$ mRNAs in the rat striatum following in vivo exposure to cocaine $(25 \mathrm{mg} / \mathrm{kg}$, i.p.). Control rats were injected with saline. Five micrograms of RNA from each brain region were fractionated through agarose formaldehyde gels, blotted, and hybridized with the c-fos probe as described in Materials and Methods. The same blot was then stripped and rehybridized with the $\alpha$-tubulin probe and then again with jun $B$ probe. The position of the $18 \mathrm{~S}$ ribosomal band is indicated.

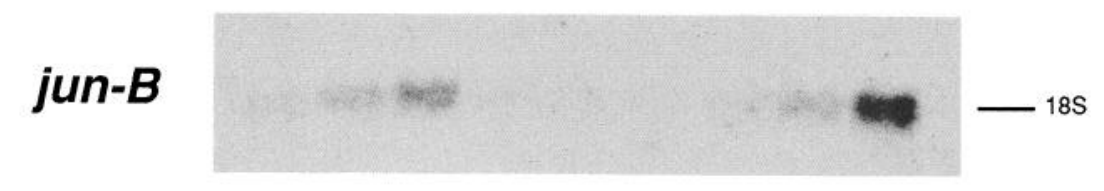

a-tubulin tom specialized transmitter phenotypes and functions (Berretta et al., 1991a,b, 1992; Moratalla et al., 1991a,b, 1992; S. Beretta, H. A. Robertson, and A. M. Graybiel, unpublished observations).

Here we show that single doses of cocaine result in temporally and spatially similar increases in c-fos and jun B mRNA expression in the striatum, but that c-jun mRNA expression is not increased in parallel. Another jun family member, jun $D$, is expressed constitutively in the striatum. These findings suggest that the molecular signaling pathways stimulated by acute exposure to psychomotor stimulants lead to gene-specific patterns of expression of genes of the leucine-zipper family of immediate-early genes. We suggest that the differential actions of the protein products of these genes may help to account for some of the selectivity in the neuronal response to psychomotor stimulants not only acutely, but also in the longer term.

\section{Materials and Methods}

Animals and drug injections. Naive male Sprague-Dawley rats (250$350 \mathrm{gm}$; Charles River) were kept under $12 \mathrm{hr}$ light/dark cycle with free access to food and water in the MIT animal facility for several days before being used, and were brought before injection to a quiet experimental room for at least $2 \mathrm{hr}$. Cocaine hydrochloride (Sigma) dissolved in saline was administered intraperitoneally $(25 \mathrm{mg} / \mathrm{kg})$ to rats at selected time points $45 \mathrm{~min}$ to $24 \mathrm{hr}$ before death, as described below. The dose was chosen on the basis of a dose-response study indicating $25 \mathrm{mg} / \mathrm{kg}$ as a dose level at which consistent, strong induction of NGFI-A mRNA (Moratalla et al., 1991a, 1992) and Fos-like immunoreactivity (Graybiel et al., 1990; R. Moratalla and A. M. Graybiel, unpublished observations) could be detected. During the posttreatment interval, the animals were observed behaviorally and maintained under low-stress conditions.

Tissue preparation. For in situ hybridization analysis, rats were killed by decapitation at $45 \mathrm{~min}$ or $1 \mathrm{hr}$ after cocaine treatment, and their brains were rapidly removed from the skull, frozen in powdered dry ice, wrapped in Parafilm, and stored at $-70^{\circ} \mathrm{C}$ for at least $2 \mathrm{~d}$. Transverse sections were cut at $15 \mu \mathrm{m}$ on a cryostat, thaw mounted onto gelatincoated microscope slides, dried under a cool air stream, and kept at $-20^{\circ} \mathrm{C}$ until hybridization.

For Northern blot analysis, rats were decapitated at $45 \min$ or 1, 2, 6 , or $24 \mathrm{hr}$ after cocaine treatment. The brains were removed, and samples from the striatum, cerebral cortex and hippocampus were quickly dissected out and frozen in liquid nitrogen under conditions designed to be RNase-free.

Hybridization probes. Oligonucleotide probes were carefully chosen to avoid sequences with high homology between members of the same gene family and at the same time to select sequences conserved across species, particularly for the jun members, for which only murine cDNA sequences were available. Probes were purchased from Bio-Synthesis Inc., Denton, TX. The probe sequences were as follows: c-fos, 48 bases long (5'-GAC-GCG-GGA-GGA-TGA-CGC-CTC-GTA-GTC-CGCGTT-GAA-ACC-CGA-GAA-CAT-3'), complementary to the base sequence encoding amino acids $2-17$ of the rat mRNA (Curran et al., 1987); jun B, 36 bases long (5'-GCC-CAG-GGA-CAC-GTT-GGGGGG-CGT-CAC-GTG-GTT-CAT-3'), complementary to the base sequence encoding amino acids 146-157 of the mouse mRNA (Ryder et al., 1988); c-jun, 45 bases long (5'-GAC-CGG-CTG-TGC-CGC-GGAGGT-GAC-ACT-GGG-AAG-CGT-GTT-CTG-GCT-3'), complementary to the base sequence of the mouse mRNA encoding amino acids 123-137 (Lamph et al., 1988); jun D, 36 bases long (5'-TGA-GGTGGC-CGC-GGT-GGC-CGC-ACC-CAG-CTG-GCT-TTG-3'), complementary to the base sequence encoding amino acids 150-161 (Ryder et al., 1989); fra-1, 45 bases long (5'-GCT-ACC-CGC-CCC-ACT-CGTGCT-GCT-GGT-ACC-ACC-TGT-GTC-CTT-CTT-3'), complementary to the base sequence encoding amino acids 181-195 (Cohen and Currant, 1988); fra-2, 45 bases long (5'-AGT-CCG-AAC-GCT-CTGGAG-GCT-GCT-GGT-TGG-GCT-CCG-ACG-TTC-3'), complementary to the base sequence encoding amino acids 197-211 (Nishima et al., 1990); and fos $B, 42$ bases long (5'-ACT-GTG-TGT-AAA-GAGAGA-AGC-CGT-CAG-GGG-GGG-TGC-GTC-3'), complementary to the base sequence encoding amino acids 271-284 (Zerial et al., 1989). Oligonucleotides complementary to c-fos, jun B, and c-jun probes were used as sense control probes to determine the specificity of the signal (see below). In addition, for Northern blotting, the jun $B$ probe was the 1.9 kilobase (kb) EcoRI fragment of ATCC 63025 (Ryder et al., 1988); the c-jun probe was either the oligonucleotide or the $2.6 \mathrm{~kb}$ EcoRI fragment of ATCC 63026 (Ryder and Nathans, 1988); and the mouse c-fos probe was derived from the $1.5 \mathrm{~kb}$ EcoRI-Sstl fragment of pc-fos-3 (Curran et al., 1983). The rat $\alpha$-tubulin probe was derived from the 1.6 kb PstI fragment of the cDNA (Lemischka et al., 1981).

In situ hybridization. All oligonucleotide probes for in situ hybridization were labeled at the $3^{\prime}$ end with $100 \mu \mathrm{Ci}$ of ${ }^{35} \mathrm{~S}-\mathrm{dATP}$ [1500 Ci/ $\mathrm{mmol}$; DuPont/New England Nuclear (NEN)]. Eighty nanograms of oligonucleotide and 30 IU of terminal deoxynucleotidyl transferase (International Biotechnologies, Inc.) were reacted with the ${ }^{35} \mathrm{~S}-\mathrm{dATP}$ in a cobalt-containing buffer at $37^{\circ} \mathrm{C}$ for $30 \mathrm{~min}$ in a total volume of $25 \mu \mathrm{l}$, 
and the reaction was stopped by adding $45 \mu \mathrm{l}$ of STE buffer $(0.1 \mathrm{M} \mathrm{NaCl}$ $10 \mathrm{~mm}$ Tris $\mathrm{HCl}, \mathrm{pH} 8 ; 1 \mathrm{~mm}$ EDTA, $\mathrm{pH} 8$ ). Each sample was purified through a Nuctrap push column (Stratagene, Palo Alto, CA), yielding a specific activity of $0.6-3.0 \times 10^{8} \mathrm{cpm} / \mu \mathrm{g}$.

Hybridizations were carried out following the procedures described by Baldino et al. (1989) and Young et al. (1986), with small modifications. Briefly, serial sections were fixed at room temperature for 5 min in $4 \%$ paraformaldehyde in $10 \mathrm{~mm}$ phosphate buffer with $120 \mathrm{~mm}$ $\mathrm{NaCl}$ and $2.7 \mathrm{~mm} \mathrm{KCl}$ (PBS), pH 7.4, rinsed three times in PBS for 5 min, placed for $10 \mathrm{~min}$ in double-strength $(2 \times)$ SSC solution $(0.15 \mathrm{M}$ $\mathrm{NaCl}, 15 \mathrm{~mm}$ sodium citrate), and defatted in a graded series of ethanols $(50 \%, 70 \%, 95 \%$, and $100 \%)$ for $3 \mathrm{~min}$ each followed by $10 \mathrm{~min}$ in chloroform. After being air dried, sections were hybridized overnight at $37^{\circ} \mathrm{C}$ in a humid chamber with $1-1.5 \times 10^{6} \mathrm{cpm}$ of one of the labeled probes described above in $100 \mu$ l of the following hybridization solution: $50 \%(\mathrm{v} / \mathrm{v})$ deionized formamide [Bethesda Research Labs (BRL)], $4 \times$ SSC; Denhardt's solution (Sigma) (bovine serum albumin, Ficoll, and polyvinylpyrrolidone, $0.02 \%$ each), $0.5 \mathrm{mg} / \mathrm{ml}$ of salmon sperm DNA (Sigma), $0.25 \mathrm{mg} / \mathrm{ml}$ yeast tRNA (BRL), 10\% (v/v) dextran sulfate (Oncor Inc., Gaithersburg, MD), $100 \mathrm{~mm}$ dithiothreitol (DTT).

After hybridization, sections were brought to room temperature and rinsed twice in $2 \times \mathrm{SSC}$ and then for $1 \mathrm{hr}$ in $2 \times \mathrm{SSC}, 1 \mathrm{hr}$ in $1 \times \mathrm{SSC}$, $30 \mathrm{~min}$ in $0.5 \times \mathrm{SSC}, 30 \mathrm{~min}$ in $0.5 \times \mathrm{SSC}$ at $37^{\circ} \mathrm{C}, 30 \mathrm{~min}$ in $0.2 \times$ $\mathrm{SSC}$, and $30 \mathrm{~min}$ in $0.1 \times \mathrm{SSC}$ at room temperature before a final dipping in $\mathrm{dH}_{2} \mathrm{O}$ for $10 \mathrm{sec}$. The temperature and salt concentration of the posthybridization solution with the highest stringency were below the melting temperatures of the oligodeoxynucleotides used. All posthybridization solutions contained $1 \%$ sodium thiosulfate, and the rinses were carried out on a shaker device.

The slides were dried and exposed to Hyperfilm $\beta$ Max (Amersham) for 3-5 weeks before being developed. Selected slides were dipped in nuclear track emulsion NTB2 (Kodak) diluted 1:1 with $0.1 \%$ Dreft dissolved in $\mathrm{dH}_{2} \mathrm{O}$. Sections were dried and stored with desiccant at $4^{\circ} \mathrm{C}$ for 6-8 weeks, and were developed in Kodak D19. The sections were stained through the emulsion with cresylecht violet.

To check for cross-hybridization between the oligonucleotide probes used, we carried out a dot blot experiment. Samples containing 0.1, 0.01 , and $0.001 \mathrm{ng}$ of denatured full-1ength cDNAs of $c-f o s, j u n B$, and $c-j u n$ were applied to a nitrocellulose membrane and were hybridized with c-fos, jun $B$, and c-jun labeled oligonucleotide probes under the same conditions as for in situ hybridization. The dot blots were processed by film autoradiography as described above.

RNA isolation and Northern blots. RNA was isolated from dissected brain tissue by the sarkosyl/guanidinium isothiocyanate/cesium chloride procedure as described in Ausubel et al. (1989), with minor modifications. RNA was fractionated through $1 \%$ agarose formaldehyde gels and blotted to nitrocellulose or GeneScreenPlus membranes (NEN). Hybridizations to GeneScreenPlus membranes were performed according to manufacturer's instructions. Hybridizations to nitrocellulose were carried out overnight in $(5 \times)$ SSPE $(150 \mathrm{~mm}$ sodium chloride, $10 \mathrm{~mm}$ sodium phosphate monobasic, 1 mM EDTA, pH 7.4), $1 \times$ Denhardt's, $100 \mu \mathrm{g} / \mathrm{ml}$ single-stranded DNA, $10 \%$ dextran sulfate, $50 \%$ formamidc at $42^{\circ} \mathrm{C}$. Prehybridization was carried out in the same solution without probe for 1-12 hr. The most stringent wash of filters for double-stranded DNA probes was at $0.1 \times \mathrm{SSPE}, 0.1 \% \mathrm{SDS}$ for $30 \mathrm{~min}$ at $65^{\circ} \mathrm{C}$. For reuse, blots were stripped of probe by incubating at $100^{\circ} \mathrm{C}$ for $10 \mathrm{~min}$ in $10 \mathrm{~mm}$ Tris, $1 \mathrm{~mm}$ EDTA, $\mathrm{pH} 8.0$. Hybridizations using oligonucleotides as probes (c-jun) were carried out according to the protocol of Henderson et al. (1991) with the hybridization and final wash temperature of $55^{\circ} \mathrm{C}$. Double-stranded DNA probes were labeled by random priming as described by Feinberg and Vogelstein (1983) and were purified on Elutip columns (Schleicher and Schuell). Oligonucleotide probes (c-jun, jun $B$, jun $D$, fos $B$, fra-1, and $f r a-2$ ) were labeled by homopolymer tailing with terminal transferase. Briefly, $1 \mathrm{pmol}$ of oligonucleotide was incubated in a $25 \mu \mathrm{l}$ reaction with $100 \mu \mathrm{Ci}$ of ${ }^{32} \mathrm{P}$-dATP and terminal transferasc $(10 \mathrm{U})$ in TdT buffer (BRL) for $1 \mathrm{hr}$ at $37^{\circ} \mathrm{C}$. Unincorporated nucleotides were removed by passing the reaction mixture over a Sephadex G50 column. Hybridization probes were used at a concentration at least $1 \times 10^{6} \mathrm{cpm} / \mathrm{ml}$.

\section{Results}

Coordinate induction of $c$-fos and jun B by cocaine

To study the influence of acute cocaine treatment on the expression of c-fos and jun $B$ in the striatum, we first carried out a Northern blot analysis of RNA isolated from the caudopu-
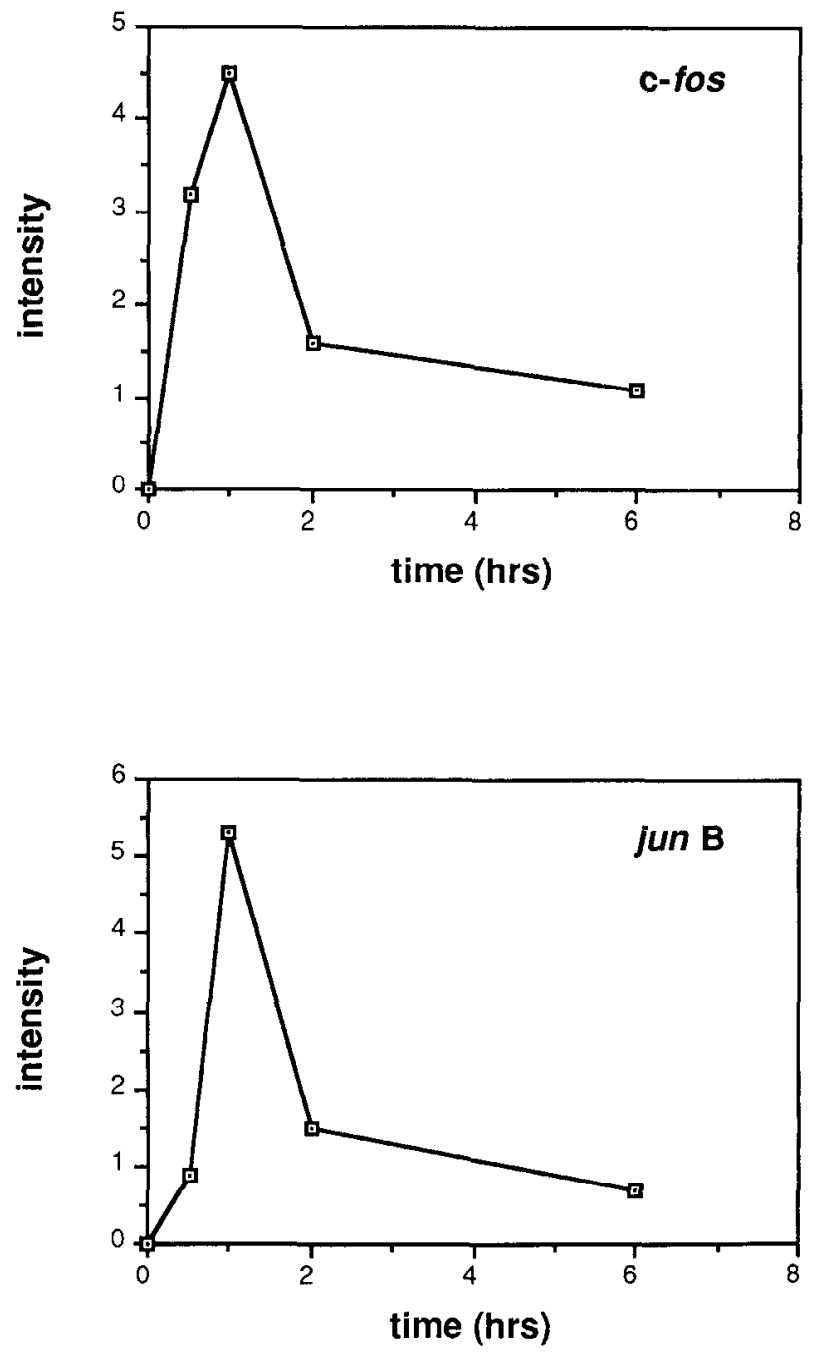

Figure 2. Time course of induction of c-fos and jun $B$ mRNAs by cocaine in the rat striatum. Rats were injected with cocaine $(25 \mathrm{mg} / \mathrm{kg}$, i.p.), and striatal RNA was isolated at indicated time points and then was analyzed by Northern blotting as described in Materials and Methods. Intensity of expression was measured on a Molecular Dynamics phosphorimager and is given in arbitrary units.

tamen 60 min after a single intraperitoneal injection of cocaine $(25 \mathrm{mg} / \mathrm{kg}$ ). We analyzed neocortical and hippocampal samples as controls for the specificity of the striatal responses. Autoradiograms of nitrocellulose blots respectively hybridized with c-fos and jun $B$ radiolabeled probes are shown in Figure 1. Cocaine induced the expression of the $2.2 \mathrm{~kb}$ - $f \circ s$ and $2.1 \mathrm{~kb}$ jun $B$ mRNAs in the striatum within $60 \mathrm{~min}$ of stimulation. For both genes, there was a lower level of induction in the neocortex and little or no expression in the hippocampus. The level of expression of c-fos in the neocortex in the saline-treated animals varied between experiments. Tissue from untreated rats showed little or no augmented expression of these proto-oncogenes.

Figure 2 shows the time course of expression of c-fos and jun $B$ evoked in the striatum in response to cocaine. Both genes were transiently induced and showed a maximum expression at approximately $60 \mathrm{~min}$ after injection. Two hours after injection, expression of $c$-fos and jun $B$ mRNAs had returned to levels only slightly elevated above baseline. Thus, c-fos and jun $B$ are transiently induced with kinetics similar to those that have been 


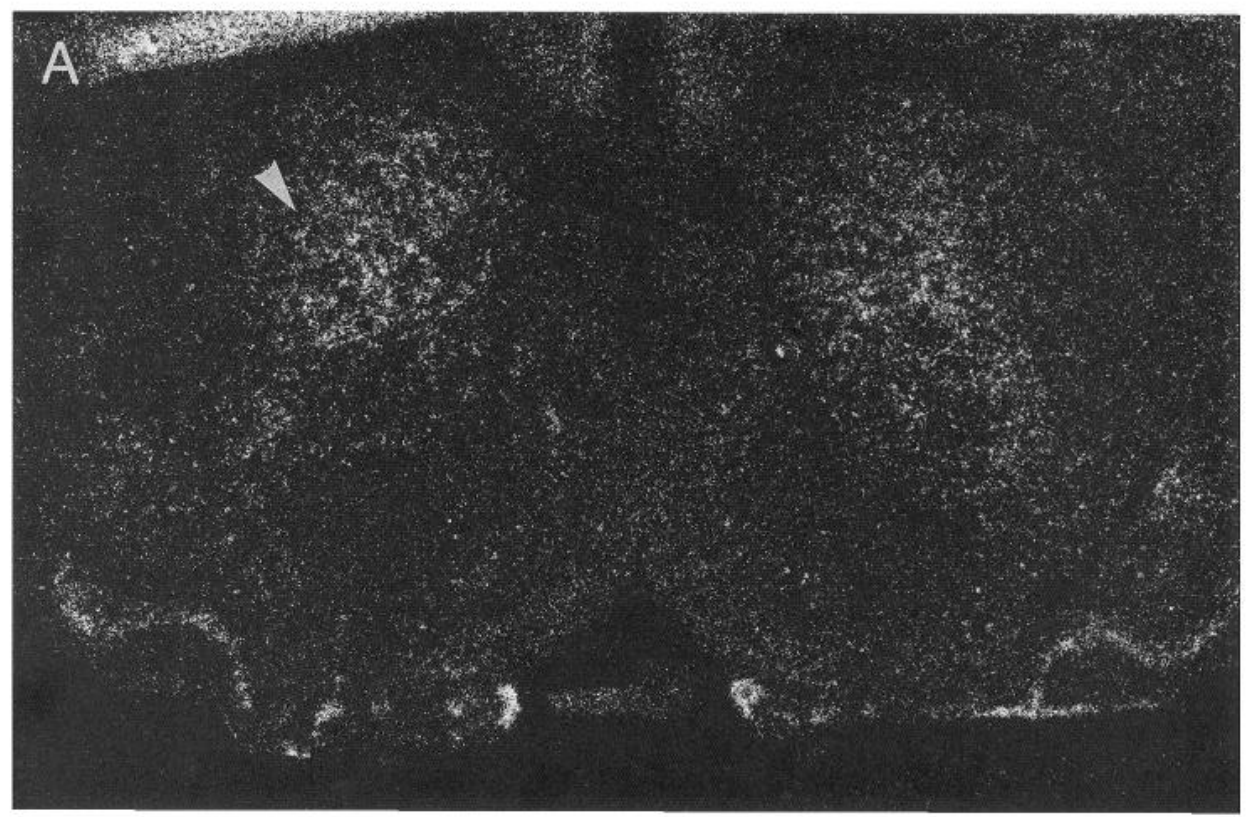

Figure 3. A, In situ hybridization autoradiogram illustrating the pattern of expression of c-fos mRNA in the striatum of a rat treated with $25 \mathrm{mg} / \mathrm{kg}$ intraperitoneal cocaine (45 min survival time). Radiolabeling appears white. White flap at top left is a tissue fold. $B$, Pattern of Nissl staining of the section shown in $A$. Note (see arrowhead in $A$ ) that there is an intense focus of mRNA labeling in a funnel-shaped region in the middle and medial caudoputamen $(C P)$, and hybridization signal appears also in the olfactory cortex $($ Olf $C)$ and in the olfactory tubercle (Olf $T$ ). $N A$, nucleus accumbens; $S$, septum. Scale bar, $1 \mathrm{~mm}$.

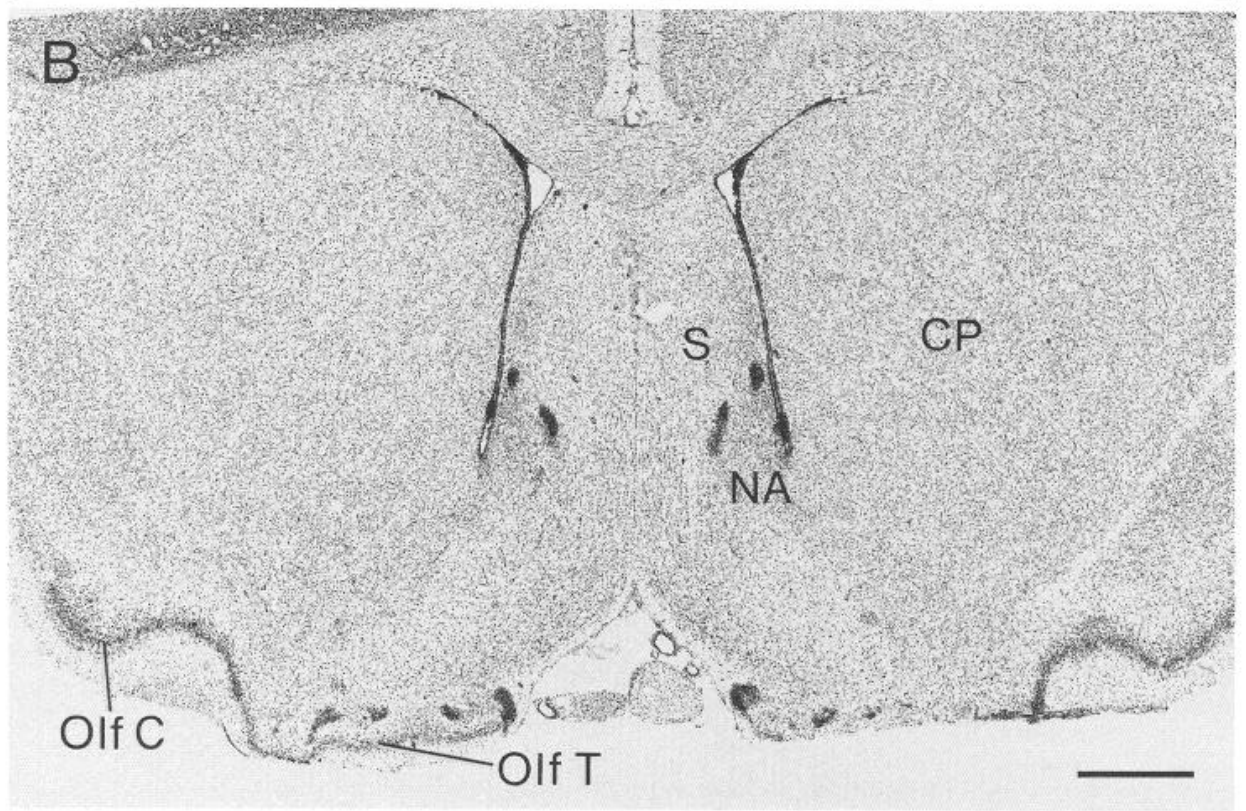

found for cultured cells (Bartel et al., 1989). The peak of expression of the two genes is $15-30$ min later than seen in cultured cells, a difference that could reflect tissue differences as well as greater time required for access of cocaine to the responding cells. The absolute levels of jun $B$ expression appeared to be higher than those of $\mathrm{c}$-fos expression both by Northern blot analysis and by in situ hybridization (see below).

\section{Sites of $c$-fos and jun B induction in the striatum following cocaine administration}

To determine the distribution of the induced c-fos and jun B expression in the striatum, we carried out in situ hybridization experiments with ${ }^{35}$ S-labeled oligonucleotide probes (Figs. 3-6). As shown in Figure $3 A$, intense activation of c-fos mRNA was evoked in the striatum by $45 \mathrm{~min}$ after a single intraperitoneal injection of cocaine $(25 \mathrm{mg} / \mathrm{kg})$. The in situ hybridization signal was characteristically strongest in the middle and dorsomedial caudoputamen, was much weaker in the lateral caudoputamen, and was intermediate to weak in the nucleus accumbens. Expression of c-fos mRNA was pronounced in the olfactory tubercle and was also strong in the piriform cortex. Very little c-fos mRNA was detectable in the caudoputamen in salinetreated controls (Fig. 5 $A^{\prime}$ ), although signal was present in the olfactory cortex. No elevated signal was visible in sections hybridized with sense c-fos probe (Fig. $6 B$ ).

Emulsion-coated sections were prepared for in situ hybridization autoradiography with the c-fos probe to identify the cellular localization of the induced mRNA within the striatum. A representative section is shown in Figure 4. Medium-sized neurons resembling medium-sized projection neurons were labeled. There was no evidence for labeling of glial cells or giant striatal neurons.

Hybridization autoradiograms for jun $B$ mRNA in the same brains (Fig. $5 B$ ) demonstrated that acute cocaine treatment induced jun $B$ mRNA in the striatum in a pattern very similar to that of $\mathrm{c}$-fos mRNA. In the saline-treated controls, only very 
low levels of expression of the jun $B$ mRNA were present in the striatum except in the olfactory tubercle, which, like the olfactory cortex, showed particularly marked expression of jun $B$ mRNA (Fig. 5 $5 B^{\prime}$ ). Sense controls (Fig. $6 C$ ) showed no signal above background other than weak labeling in the olfactory cortex. The c-fos and jun $B$ oligonucleotide probes were gene specific and did not cross-hybridize to c-fos or jun B cDNAs on dot blots under the hybridization conditions used for the in situ hybridization (see sequences in Materials and Methods, and data not shown).

\section{Lack of induction of c-jun by cocaine}

Because c-jun is often coordinately regulated with jun B (Lamph et al., 1988; Ryder and Nathans, 1988), we tested whether this gene is also induced by cocaine in the striatum. From Figures $5 C$ and $6 D$, it is clear that no induction was found at a $1 \mathrm{hr}$ time point by in situ hybridization autoradiography. A similarly negative result was obtained by Northern blot analysis (Fig. 7). Little or no induction of c-jun could be detected in the striatum at $1,6,12$, or $24 \mathrm{hr}$ after injection of cocaine (Fig. 7). Neither technique demonstrated induction of c-jun in the hippocampus or cerebral cortex (data not shown).

As controls for detection of c-jun mRNA, we carried out two experiments. First, for the Northern blot analysis, RNA was extracted from Balb/c-3T3 cells (clone A31) after treatment with serum and cycloheximide for $1 \mathrm{hr}$. As expected, this treatment induced 3.2 and $2.7 \mathrm{~kb}$ c-jun mRNAs (Fig. 7). To test the efficacy of our c-jun probe for in situ hybridization, we used it, along with probes for c-fos and jun $B$, to assay for induction of the three genes in the hippocampus following treatment with pentylenetetrazol (Metrazol, $50 \mathrm{mg} / \mathrm{kg}, 1 \mathrm{hr}$ survival time). This seizure-inducing stimulation is known to lead to rapid induction of all three mRNAs (Saffen et al., 1988), and this pattern of coinduction of c-fos, jun B, and c-jun was evident in our experiments (Fig. 8). There was marked expression of the three mRNAs in the dentate gyrus and moderate expression in the CA fields. Coexpression was not, however, evident everywhere in these brains. For example, only with the c-fos mRNA probe was strong activation apparent in the cortex and thalamus (Fig. $8 A)$.

\section{Expression of other fos/jun family genes in the striatum in response to cocaine}

We tested for induction of other fos/jun family genes in the striatum of cocaine-treated animals by carrying out Northern blot analysis with oligonucleotide probes. Jun D showed constitutive levels of expression at all time points examined (Fig. 7). Thus, all three jun family genes show different patterns of expression in the striatum. We found that $f r a-1$ and $f r a-2$ were expressed at low levels in the striatum, and that their expression did not change appreciably after cocaine injection (data not shown). Fos $B$ mRNA expression was undetectable by Northern blot of striatal RNA at any time before or after cocaine administration. Thus, striatal expression of the fos family members also exhibits heterogeneity in responsiveness to cocaine.

\section{Discussion}

We have found that in the rat's striatum, in vivo exposure to cocaine rapidly and transiently induces c-fos and jun $B$, members of the leucine-zipper AP-1 transcription factor family. The parallel kinetics of induction of the two genes, and the similarity in the anatomical distributions of their mRNAs, suggest that

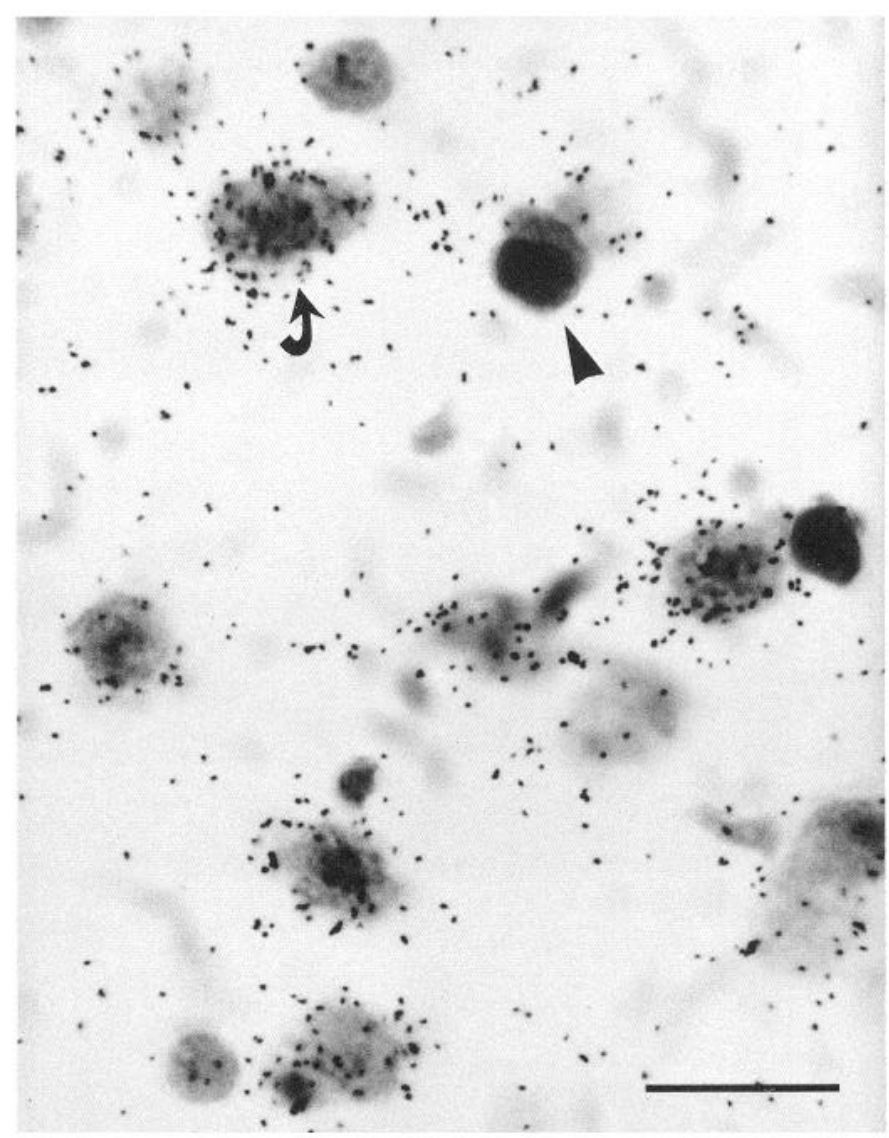

Figure 4. Photomicrograph of emulsion autoradiogram from a cocaine-treated rat ( $25 \mathrm{mg} / \mathrm{kg}$, i.p.; 45 min survival time), illustrating c-fos mRNA in situ hybridization signal (black dots in autoradiogram) associated with medium-sized neurons of caudoputamen (example at curved arrow). Labeling of glial cells (example at arrowhead) was not observed. Scale bar, $20 \mu \mathrm{m}$.

their regulation is coordinate. By contrast, another member of this immediate-early gene transcription factor family, c-jun, was not induced in the striatum following cocaine treatment, and a third, jun $D$, was constitutively expressed. This evidence for a selective pattern of fos/jun gene induction, taken together with previous reports (Graybiel et al., 1990; Young et al., 1991), strongly suggests that the genomic response to cocaine is not only brain region specific but also gene specific.

With a polyclonal antiserum raised against a conserved c-Fos peptide, Young et al. (1991) observed multiple immunoreactive proteins by Western blot analysis of striatal nuclei. In their study, the expression of a $55 \mathrm{kDa}$ and of a $35 \mathrm{kDa}$ protein was markedly enhanced by cocaine administration. Proteins of 35 , 41 , and $44 \mathrm{kDa}$ also showed significant basal levels of expression. The relationships between these protein bands and the known fos gene family members were not determined in this study. However, the $55 \mathrm{kDa}$ protein is presumably c-Fos, and its induction would be consistent with our observations on the induction of the c-fos mRNA by cocaine.

Studies on the regulation of c-fos, c-jun, and jun B by growth factors in fibroblasts and $\mathrm{PC} 12$ cells in vitro indicate that these genes can be coinduced, but that the coinduction is specific for particular stimulus conditions (Lamph et al., 1988; Ryder and Nathans, 1988; Ryder et al., 1988; Bartel et al., 1989; Mechta et al., 1989; Auwerx et al., 1990). The pattern of c-fos, c-jun, and jun $B$ expression that we have observed in the striatum in 


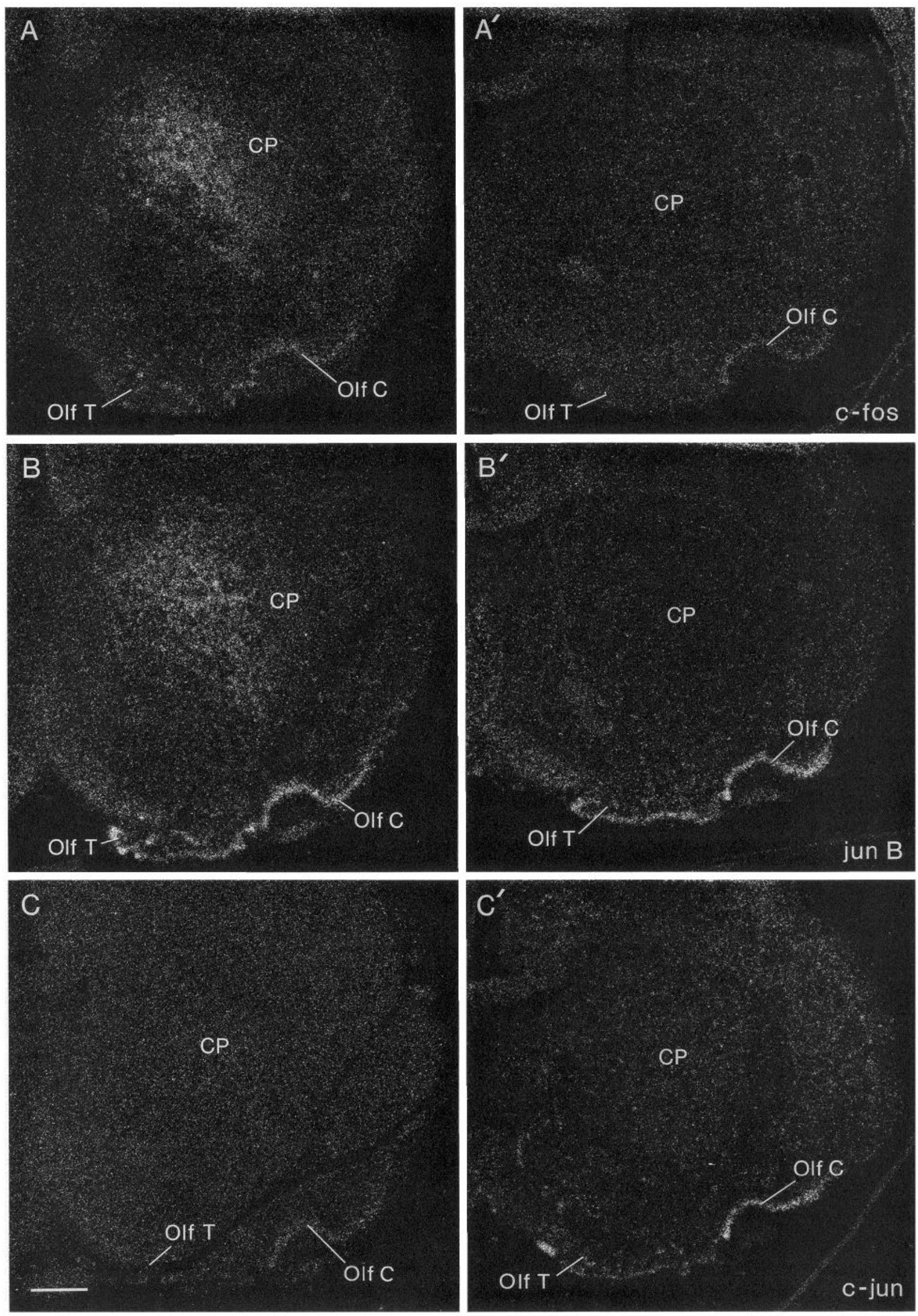



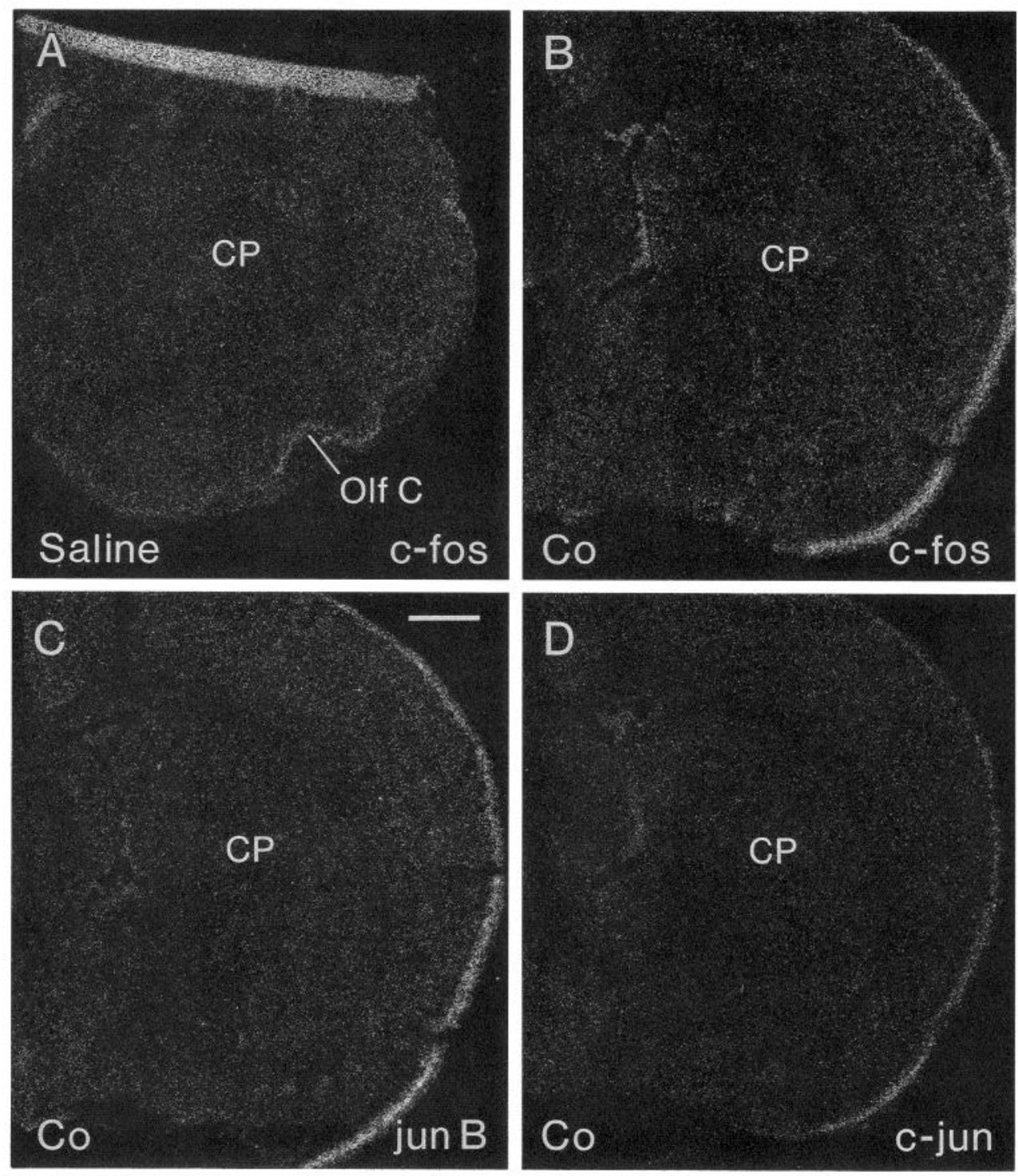

Figure 6. Control experiments demonstrating specificity of gene induction patterns: in situ hybridization autoradiograms from saline-treated rat brain $(A)$ and from cocaine-treated rat brains (B-D; $25 \mathrm{mg} / \mathrm{kg}$, cocaine, i.p.; $1 \mathrm{hr}$ survival time). Sections illustrated were processed with radiolabeled anti-sense probe for c- $f o s(A)$, and with radiolabeled sense probes for c-fos $(B)$, jun $B$ $(C)$, and c-jun $(D)$. Except for very weak signal sometimes present in the olfactory cortex (Olf $C$; see $A$ ), no labeling above background was present. White rims around some of the sections represent edge artifact; white flap in $A$ is tissue fold. $C P$, caudoputamen. Scale bar, $1 \mathrm{~mm}$. response to cocaine is strikingly similar to that induced by membrane depolarization of PC12 cells (Bartel et al., 1989) and by cAMP in fibroblasts (Mechta et al., 1989). In PC12 cells, NGF and EGF can induce c-fos, jun $B$, and c-jun coordinately, but membrane depolarization induced by $\mathrm{KCl}$ or nicotine stimulates the induction of c-fos and jun B without coordinate induction of c-jun (Bartel et al., 1989). In fibroblasts, cAMP analogs induce c-fos and jun B, but inhibit c-jun (Mechta et al., 1989). In addition, previous work on PC12 cells has implicated calcium and voltage-gated calcium channels in the signaling pathways by which membrane depolarization induces c-fos (Morgan and Curran, 1986).

Thus, if striatal neurons are responding in a similar manner, plausible candidates for the second messengers mediating cocaine's induction of c-fos and jun B are intracellular calcium or cAMP, or a combination of the two. Induction via the cAMP/ protein kinase A pathway would be consistent with the fact that the dopamine D1-like receptor antagonist SCH23390 blocks induction of Fos and Fos-related antigens by cocaine (Graybiel et al., 1990; Young et al., 1991; Berretta et al., 1992). Stimulation of D1-like receptors is known to generate a cAMP second signal (Stoof and Kebabian, 1981). In Xenopus oocytes, it has been reported that some D1-like receptors are positively linked to inositol phospholipid (inositol trisphosphate) messenger systems (Mahan et al., 1990). Thus, induction via a D1-like receptor-mediated increase in $\mathrm{Ca}^{2+}$ flux may also occur. These results also leave open the possibility that other receptor systems are involved, including 5-HT receptors, given that $\mathrm{SCH} 23390$ is known to block some 5-HT receptors in rodent brain (Bischoff et al., 1986). Responses mediated by cAMP and $\mathrm{Ca}^{2+}$ are known to be generated by some 5-HT receptor subtypes as well (Julius, 1991).

Figure 5. A-C, Demonstration of differential expression of fos/jun genes induced in the striatum by cocaine ( $25 \mathrm{mg} / \mathrm{kg}$, i.p.; $1 \mathrm{hr}$ survival time). In situ hybridization autoradiograms illustrate selective induction of c-fos mRNA $(A)$ and jun $B$ mRNA $(B)$ but not c-jun mRNA $(C)$ in the caudoputamen following cocaine treatment. $A^{\prime}-C^{\prime}$, In situ hybridization autoradiograms from control rats treated with intraperitoneal saline $1 \mathrm{hr}$ before tissue harvesting, prepared with the same probes for c-fos $\left(A^{\prime}\right)$, jun $B\left(B^{\prime}\right)$, and c-jun $\left(C^{\prime}\right)$ used in the cocaine experiments. Little signal is present following saline treatment except in the olfactory cortex and olfactory tubercle. Abbreviations are as in Figure 3 . Scale bar, $1 \mathrm{~mm}$. 
c-jun

striatum

NT $1 \mathrm{~h} \quad 6 \mathrm{~h} \quad 12 \mathrm{~h} \quad 24 \mathrm{~h}$

3T3

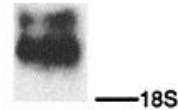

jun B

striatum

NT 1h $6 \mathrm{~h} \quad 12 \mathrm{~h} \quad 24 \mathrm{~h}$

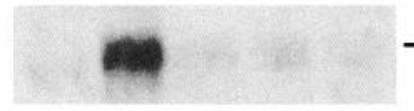

$-185$

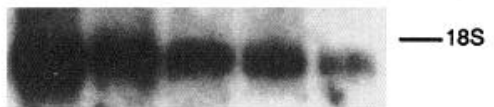

jun D

striatum

NT 1h $6 h \quad 12 h \quad 24 h$
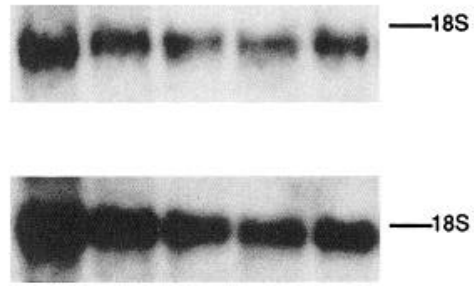

\section{$\alpha$-tubulin}

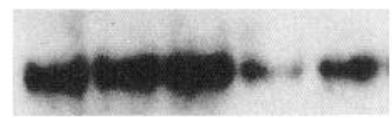

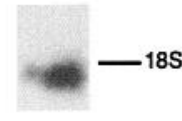

Figure 7. Northern blot analysis demonstrating different patterns of expression of jun family mRNAs in the rat striatum. Rats were injected intraperitoneally with cocaine $(25 \mathrm{mg} / \mathrm{kg})$ and were killed at indicated times after injection, or were untreated $(N T)$. For each time point, $5 \mu \mathrm{g}$ of RNA were fractionated through formaldehyde-agarose gels, blotted to nitrocellulose, and hybridized to c-jun, jun $B$, or jun $D$ probes. In parallel, $5 \mu \mathrm{g}$ of RNA from quiescent Balb/c-3T3 cells (clone A31) that were treated for $3 \mathrm{hr}$ with $10 \%$ calf serum and $10 \mu \mathrm{g} / \mathrm{ml}$ cycloheximide were hybridized to the c-jun probe. After exposure to x-ray film, each blot was stripped and rehybridized to a probe for $\alpha$-tubulin.
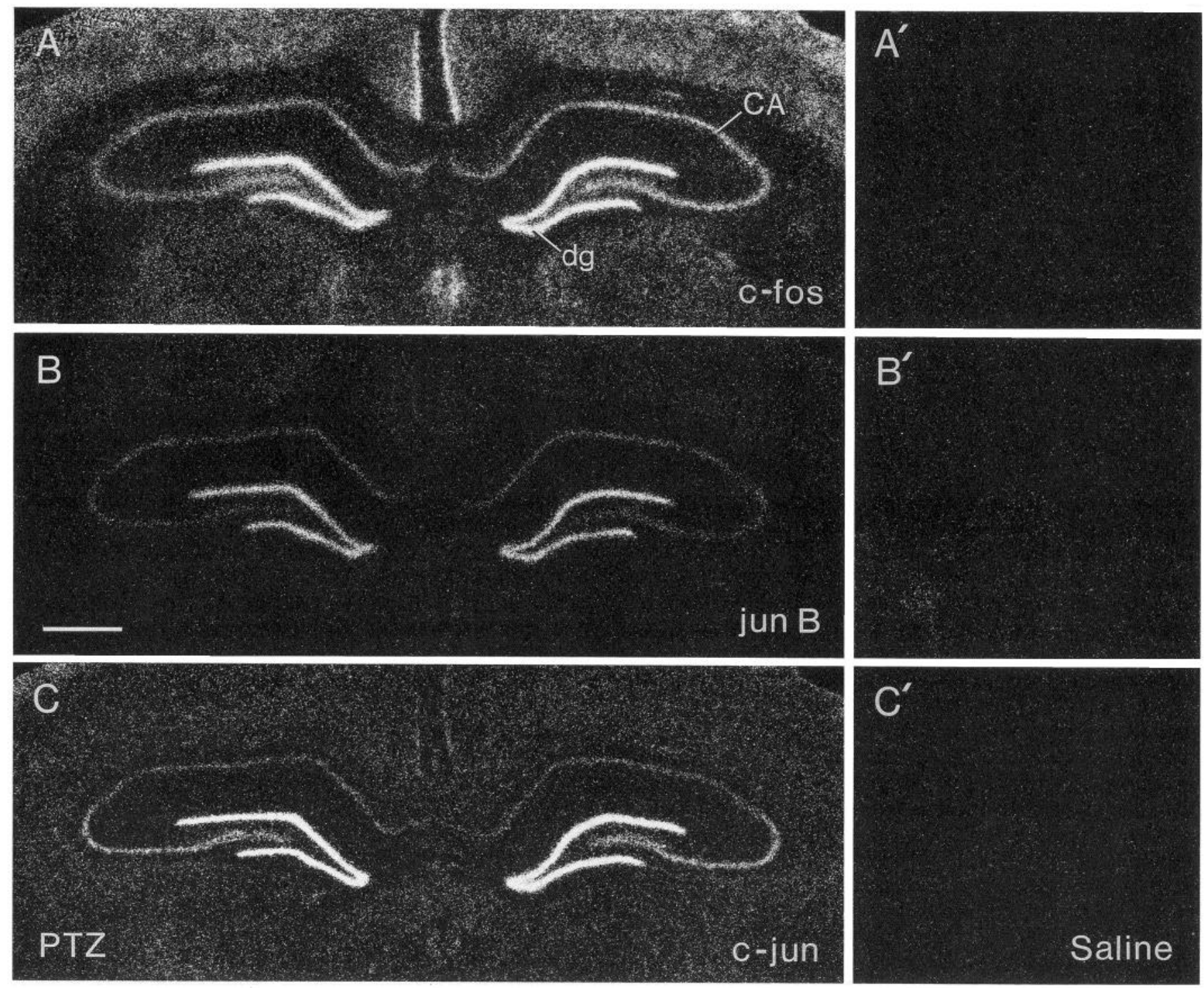

Figure 8. Demonstration of coordinate induction of fos/jun mRNAs in hippocampus in rats treated with metrazol 1 hr before death. In situ hybridization autoradiograms of sections through the hippocampus show coinduction of c-fos $(A)$, jun $B(B)$, and c-jun $(C)$ mRNAs in the dentate gyrus $(d g)$ and CA fields of the hippocampus $(C A)$. $A^{\prime}-C^{\prime}$ demonstrate lack of hybridization signal in hippocampus of saline-treated control rats (only right hippocampus is shown in each panel). The in situ hybridization was carried out with the same probes used for the cocaine experiments (Figs. 3-6). Scale bar, $1 \mathrm{~mm}$. 
A key question raised by our findings is whether the complexity of the immediate-early gene response to cocaine can be understood in terms of what is known about transcriptional control by elements upstream of these genes. The analysis of regulatory elements of c-fos, c-jun, and jun B is far from complete, but the information so far available suggests a plausible accounting for the divergent patterns we found. The c-fos promoter, the best studied of these promoters, contains elements that are responsive to platelet-derived growth factor (PDGF), serum, cAMP, phorbol esters, and calcium (Verma and SassoneCorsi, 1987). The element at -65 upstream of the human c-fos gene is calcium- and cAMP-responsive (CaRE/CRE), and would thcrcforc be a good candidate element for mediating the response to cocaine (Sheng et al., 1988, 1990; Berkowitz et al., 1989). The jun $B$ promotor does not have a serum response element such as c-fos does or a 12-0-tetradecanoylphorbol 13acetate (TPA)-responsive element (TRE or AP-1 site) like the one shown to be important in the mediation of c-jun induction (Angel et al., 1988b). However, the jun B promoter does contain a novel inverted repeat element that can mediate responses to protein kinase A and protein kinase C (de Groot et al., 1991). Elements of the jun $B$ promoter that might respond to calcium have not been characterized.

The major regulatory element upstream of c-jun appears to be a TRE or AP-1-type site (Angel et al., 1988b). In some cells, the c-jun promotor is responsive to phorbol esters, but not to elevated levels of cAMP (Chiu et al., 1989; Auwerx et al., 1990). When the c-jun TRE is placed upstream of a thymidine kinase promoter chloramphenicol acetyl transferase gene fusion (TK CAT) construct and is cotransfected with protein kinase A, CAT expression is inhibited (de Groot et al., 1991). Moreover, the c-jun TRE can be inhibited by jun $B$ expression (Chiu et al., 1989). The coordinate induction of c-fos and jun $B$, but not $c-j u n$, by cocaine could, from this evidence, result from the generation of a cAMP and/or calcium-mediated second signal that activates $\mathrm{c}$-fos expression through $-65 \mathrm{CaRE} / \mathrm{CRE}$ element and $j u n B$ expression through the inverted repeat element. C-jun would not be expressed either because the protein kinase $C$ pathway is not activated or because it is actively repressed by cAMP or jun $B$.

Members of the fos/jun family of transcription factor genes have been proposed to be couplers between short-term neural activity (seconds to minutes) and longer-term changes in neural signaling (hours/day) (Berridge, 1986; Goelet et al., 1986; Morgan and Curran, 1989; Dash et al., 1990). Cocaine is known to have extensive long-term effects, and we show here that even acute cocaine treatment induces significant levels of a c-fos and jun $B$ out within striatal neurons. This complex would be likely to have positive and/or negative regulatory effects on genes containing AP-1-like regulatory elements. Moreover, the fact that c-Fos/Jun B complexes can interact with CREs suggests that the induction of these genes could further influence signaling through these elements (Zerial et al., 1989; Dwarki et al., 1990; Macgregor et al., 1990; Ryseck and Bravo, 1991). The target genes for such effects are unknown, but might include genes that code for molecules involved in neurotransmission (Sonnenberg et al., 1989b; Graybiel, 1990; Jiang et al., 1990; Nestler et al., 1990; Gerfen et al., 1991; Naranjo et al., 1991).

Our results raise the possibility that the c-Fos/Jun B transcription factor complex may play a physiological role in the response of striatal neurons to psychomotor stimulants. We have also shown that cocaine and amphetamine rapidly induce
NGFI-A (zif 268, egr 1) in striatal neurons in anatomical patterns similar to those shown here for c-fos and jun B (Moratalla et al., 1991 a,b, 1992). Together, these findings point to a highly selective induction of immediate-early genes by agents stimulating monoamine receptors in the striatum. These differential patterns of induction may help in identifying the molccular effects of dopamine and other monoamines on striatal neurons.

\section{References}

Abate C, Luk D, Gentz R, Rauscher F, Curran T (1990a) Expression and purification of the leucine zipper and the DNA-binding domains of Fos and Jun: both Fos and Jun directly contact DNA. Proc Natl Acad Sci USA 87:1032-1036.

Abate C, Luk D, Gagne E, Roedert R, Curran T (1990b) Fos and Jun cooperate in transcriptional regulation via heterologous activation domains. Mol Cell Biol 10:5532-5535.

Angel P, Allegretto EA, Okino ST, Hattori K, Boyle WJ, Hunter T, Karin M (1988a) Oncogene jun encodes a sequence-specific transactivator similar to AP-1. Nature 332:166-171.

Angel P, Hattori K, Smeal T, Karin M (1988b) The jun proto-oncogene is positively antoregulated by its product, Jun/AP-1. Cell 55:875885 .

Ausubel FM, Brent R, Kingston RE, Moore DD, Seidman JG, Smith JA, Struhl K (1989) Current protocols in molecular biology. New York: Wiley-Interscience.

Auwerx J, Staels B, Sassone-Corsi P (1990) Coupled and uncoupled induction of fos and jun transcription by different second messengers in cells of hematopoietic origin. Nucleic Acids Res 18:221-228.

Baldino F Jr, Chesselet MF, Lewis ME (1989) High resolution in situ hybridization histochemistry. Methods Enzymol 168:761-777.

Bartel DP, Sheng M, Lau LF, Greenberg ME (1989) Growth factors and membrane depolarization activate distinct programs of early response gene expression: dissociation of fos and jun induction. Genes Dev 3:304-313.

Berkowitz LS, Riabowol KT, Gilman MZ (1989) Multiple sequence elements of a single functional class are required for cyclic AMP responsiveness of the mouse c-fos promoter. Mol Cell Biol 9:42724281.

Berretta S, Christie R, Robertson HA, Graybiel AM (1991a) Molecular characteristics of striatal neurons that express Fos on stimulation by indirect dopamine agonists. Soc Neurosci Abstr 17:853.

Berretta S, Robertson HA, Graybiel AM (1991b) Immediate-early gene expression induced by the psychostimulant cocaine is specific to subpopulations of striatal projection neurons. Eur J Neurosci Suppl 4:166.

Berretta S, Robertson HA, Graybiel AM (1992) Dopamine and glutatmate agonists stimulate neuron-specific expression of Fos-like protein in the striatum. J Neurophysiol 67:767-777.

Berridge M (1986) Second messenger dualism in neuromodulation and memory. Nature 323:294-295.

Bischoff S, Heinrich M, Sonntag JM, Krauss J (1986) The D-1 dopamine receptor antagonist SCH 23390 also interacts with brain serotonin (5- $\mathrm{HT}_{2}$ ) receptors. Eur J Pharmacol 129:367-370.

Bohmann D, Bos TJ, Admon A, Nishimura T, Vogt PK, Tijan R (1987) Human proto-oncogene c-jun encodes a DNA binding protein with structural and functional properties of transcription factor AP-1. Science 238:1386-1392.

Chiu R, Boyle WJ, Meek J, Smeal T, Hunter T, Karin M (1988) The c-Fos protein interacts with c-Jun/AP-1 to stimulate transcription of AP-1 responsive genes. Cell 54:541-552.

Chiu R, Angel P, Karin M (1989) jun-B differs in its biological properties from, and is a negative regulatory of, c-jun. Cell 59:979-986.

Cochran BH, Zullo J, Verma IM, Stiles CD (1984) Expression of the c-fos gene and of a fos-related gene is stimulated by platelet-derived growth factor. Science 226:1080-1082.

Cohen DR, Currant T (1988) Fra-1, a serum-inducible, cellular immediate-early gene that encodes a fos-related antigen. Mol Cell Biol 8:2063-2069.

Cole AJ, Saffen DW, Baraban JM, Worley PF (1989) Rapid increase of an immediate early gene messenger RNA in hippocampal neurons by synaptic NMDA receptor activation. Nature 340:474-476.

Curran T, Franza BR (1988) Fos and Jun: the AP-1 connection. Cell 55:395-397. 
Curran T, MacConnell WP, van Straaten F, Verma IM (1983) Structure of the FBJ murine osteosarcoma virus genome: molecular cloning of its associated helper virus and the cellular homolog of the c-fos gene from mouse and human cells. Mol Cell Biol 3:914-921.

Curran T, Gordon MB, Rubino KL, Sambucetti LC (1987) Isolation and characterization of the c-fos (rat) cDNA and analysis of posttranslational modification in vitro. Oncogene 2:79-84.

Dash PK, Hochner B, Kandel ER (1990) Injection of the cAMPresponsive element into the nucleus of Aplysia sensory neurons blocks long-term facilitation. Nature 345:718-721.

de Groot RP, Auwerx J, Karperien M, Staels B, Kruijer W (1991) Activation of $j u n \mathrm{~B} 24$ by PCK and PKA signal transduction through a novel cis-acting clement. Nuclcic Acids Res 19:775-781.

Distel RJ, Ro H-S, Rosen BS, Groves DL, Spiegelman BM (1987) Nucleoprotein complexes that regulate gene expression in adipocyte differentiation: direct participation of c-fos. Cell 49:835-844.

Dragunow M, Robertson HA (1988) Seizure-inducible c-fos protein(s) in mammalian neurons. Trends Pharmacol Sci 9:5-6.

Dwarki VJ, Montminy M, Verma IM (1990) Both the basic region and the 'leucine zipper' domain of the cyclic AMP response element binding (CREB) protein are essential for transcriptional activation. EMBO J 9:225-232.

Feinberg AP, Vogelstein B (1983) A technique for radiolabeling DNA restriction endonuclease fragments to high specific activity. Anal Biochem 132:6-13.

Gall C, Lauterborn J, Isackson P, White J (1990) Seizures, neuropeptide regulation, and mRNA expression in the hippocampus. Prog Brain Res 83:371-390.

Gall C, Murray K, Isackson PJ (1991) Kainic acid-induced seizures stimulate increased expression of nerve growth factor mRNA in rat hippocampus. Mol Brain Res 9:113-123.

Gerfen CR, McGinty JF, Young WS III (1991) Dopamine differentially regulates dynorphin, substance $P$, and enkephalin expression in striatal neurons: in situ hybridization histochemical analysis. J Neurosci 11:1016-1031.

Goelet P, Castellucci VF, Schacher S, Kandel ER (1986) The long and the short of long-term memory-a molecular framework. Nature 322: 419-422.

Graybiel AM (1990) Neurotransmitters and neuromodulators in the basal ganglia. Trends Neurosci 13:244-254.

Graybiel AM, Moratalla R, Robertson HA (1990) Amphetamine and cocaine induce drug-specific activation of the c-fos gene in striosomematrix and limbic subdivisions of the striatum. Proc Natl Acad Sci USA 87:6912-6916.

Greenberg ME, Ziff EB (1984) Stimulation of 3T3 cells induces transcription of the c-fos proto-oncogene. Nature 311:433-442.

Halazometis TD, Georgopoulos K, Greenberg ME, Leder P (1988) C-Jun dimerizes with itself and with c-Fos forming complexes of different DNA binding affinities. Cell 55:917-924.

Henderson GS, Conary JT, Davidson JM, Steward SJ, House FS, McCurley TL (1991) A reliable method for Northern blot analysis using synthetic oligonucleotide probes. Biotechniques 10:190-197.

Jiang HK, McGinty JF, Hong JS (1990) Differential modulation of striatonigral dynorphin and enkephalin by dopamine receptor subtypes. Brain Res 507:57-64.

Julius D (1991) Molecular biology of serotonin receptors. Annu Rev Neurosci 14:335-360.

Kourazides T, Ziff E (1988) The role of the leucine zipper in the fosjun interaction. Nature 336:646-656.

Kovary K, Bravo R (1991) Expression of different Jun and Fos proteins during the G0-to-G1 transition in mouse fibroblasts: in vitro and in vivo associations. Mol Cell Biol 11:2451-2459.

Lamph WW, Wamsley P, Sassone-Corsi P, Verma IM (1988) Induction of proto-oncogene jun/AP-1 by serum and TPA. Nature 334: 629-631.

Lamph WW, Dwarki VJ, Ofir R, Montminy M, Verma IM (1990) Negative and positive regulation by transcription factor cAMP response element-binding protein is modulated by phosphorylation. Proc Natl Acad Sci USA 87:4320-4324.

Landschulz WH, Johnson PF, McKnight SL (1988) The leucine zipper: a hypothetical structure common to a new class of DNA binding proteins. Science 240:1759-1764.

Lee W, Mitchell P, Tjian R (1987) Purified transcription factor AP-1 interacts with TPA-inducible enhancer elements. Cell 49:741-752.

Lemischka IR, Farmer S, Racaniello VR, Sharp PA (1981) Nucleotide sequence and evolution of a mammalian $\alpha$-tubulin messenger RNA. J Mol Biol 151:101-120.

Macgregor PF, Abate C, Curran T (1990) Direct cloning of leucine zipper proteins: Jun binds cooperatively to the CRE with CRE-BP1. Oncogene 5:451-458.

Mahan LC, Burch RM, Monsma FJ Jr, Sibley DR (1990) Expression of striatal D1 dopamine receptors coupled to inositol phosphate production and $\mathrm{Ca}^{2+}$ mobilization in Xenopus oocytes. Proc Natl Acad Sci USA 87:2196-2200.

Mechta F, Piette J, Hirai SI, Yaniv M (1989) Stimulation of protein kinase $\mathrm{C}$ or protein kinase A mediated signal transduction pathways shows three modes of response among serum inducible genes. New Biol 1:297-304.

Moratalla R, Robertson HA, Graybiel AM (1991a) NGFI-A mRNA expression is induced in the rat striatum by indirect dopamine agonists. Soc Neurosci Abstr 17:853.

Moratalla R, Robertson HA, Graybiel AM (1991b) The immediateearly gene $N G F I$-A (zif 268 , egr 1 ) is selectively induced in the striosomal system following acute amphetamine treatment. Eur J Neurosci Suppl 4:274.

Moratalla R, Robertson HA, Graybiel AM (1992) Dynamic regulation of NGFI-A (zif 268, egr 1) gene expression in the striatum. J Neurosci 12:2609-2622.

Morgan JI, Curran T (1986) Role of ion flux in the control of c-fos expression. Nature 322:552-555.

Morgan JI, Curran T (1989) Stimulus-transcription coupling in neurons: role of cellular immediate-early genes. Trends Neurosci 12:459462.

Muller R, Bravo R, Burckhardt J, Curran T (1984) Induction of c-fos gene and protein by growth factors precedes activation of $\mathrm{c}-m y c$. Nature 312:716-720.

Nakabeppu Y, Ryder K, Nathans D (1988) DNA binding activities of three murine Jun proteins: stimulation by Fos. Cell 55:907-915.

Naranjo JR, Mellström B, Achaval M, Sassone-Corsi P (I991) Molecular pathways of pain: Fos/Jun-mediated activation of a noncanonical AP-1 site in the prodynorphin gene. Neuron 6:607-617.

Nestler EJ, Terwilliger RZ, Walker JR, Sevarino KA, Duman RS (1990) Chronic cocaine treatment decreases levels of the $G$ protein subunits $\mathrm{G}_{\mathrm{i} \alpha}$ and $\mathrm{G}_{0 \alpha}$ in discrete regions of the rat brain. $\mathrm{J}$ Neurochem 55 : 1079-1082.

Nishima II, Sata II, Suzuki T, Sata M, Iba H (1990) Isolation and characterization of fra-2, an additional member of the fos gene family. Proc Natl Acad Sci USA 87:3619-3623.

O'Shea EK, Rutkowski R, Stafford WF III, Kim PS (1989) Preferential heterodimer formation by isolated leucine zippers from Fos and Jun. Science 245:646-648.

Rauscher FJ, Voulalas PJ, Franza BR Jr, Curran T (1988a) Fos and Jun bind cooperatively to the AP-1 site: reconstruction in vitro. Genes Dev 2:1687-1699.

Rauscher FJ III, Sambucetti LC, Curran T, Distel RJ, Spiegelman BM (1988b) Common DNA binding site for Fos protein complexes and transcription factor AP-1. Cell 52:471-480.

Ryder K, Nathans D (1988) Induction of protooncogene c-jun by serum growth factors. Proc Natl Acad Sci USA 85:8464-8467.

Ryder K, Lau LF, Nathans D (1988) A gene activated by growth factors is related to the oncogene v-jun. Proc Natl Acad Sci USA 85:14871491.

Ryder K, Lanahan A, Perez-Albuerne E, Nathans D (1989) Jun-D: a third member of the jun gene family. Proc Natl Acad Sci USA 86: 1500-1503.

Ryseck R-P, Bravo R (1991) C-Jun, jun B, and jun D differ in their binding affinities to AP-1 and CRE consensus sequences: effect of Fos proteins. Oncogene 6:533-542.

Saffen DW, Cole AJ, Worley PF, Christy BA, Ryder K, Baraban JM (1988) Convulsant-induced increase in transcription factor messenger RNAs in rat brain. Proc Natl Acad Sci USA 85:7795-7799.

Sassone-Corsi P, Ransone LJ, Lamph WW, Verma IM (1988) Direct interaction between fos and jun nuclear oncoproteins: role of the "leucine zipper" domains. Nature 336:692-695.

Schutte J, Viallet J, Nau M, Segal S, Fedorko J, Minna J (1989) jun-B inhibits and c-fos stimulates the transforming and trans-activating activities of c-jun. Cell 59:987-997.

Sheng M, Greenberg ME (1990) The regulation and function of c-fos and other immediate early genes in the nervous system. Neuron 4: $477-485$. 
Sheng M, Dougan ST, McFadden G, Greenberg ME (1988) Calcium and growth factor pathways of c-fos transcriptional activation require distinct upstream regulatory sequences. Mol Cell Biol 8:2787-2796.

Sheng M, McFadden G, Greenberg ME (1990) Membrane depolarization and calcium induce c-fos transcription via phosphorylation of transcription factor CREB. Neuron 4:571-582.

Sonnenberg JL, Macgregor LPF, Curran T, Morgan JI (1989a) Dynamic alterations occur in the levels and composition of transcription factor AP-1 complexes after seizure. Neuron 3:359-365.

Sonnenberg JL, Rauscher FJ, Morgan JI, Curran T (1989b) Regulation of proenkephalin by Fos and Jun. Science 246:1622-1625.

Stoof JC, Kebabian JW (1981) Opposing roles for D-1 and D-2 dopamine receptors in efflux of cAMP from rat striatum. Nature 294: 366-368.

Verma IM, Sassone-Corsi P (1987) Proto-oncogene fos: complex but versatile regulation. Cell 51:513-514.

Vinson CR, Sigler PB, McKnight SL (1989) Scissors-grip model for DNA recognition by a family of leucine zipper proteins. Science 246 : 911-916.

Watson MA, Milbrandt J (1989) The NGFI-B gene, a transcriptionally inducible member of the steroid receptor gene superfamily: genomic structure and expression in rat brain after seizure induction. Mol Cell Biol 9:4213-4219.

White JD, Gall CM (1987) Differential regulation of neuropeptide and proto-oncogene mRNA content in the hippocampus following recurrent seizures. Mol Brain Res 3:21-29.

Wisden W, Errington ML, Williams S, Dunnett SB, Waters C, Hitchcock D, Evan G, Bliss TV, Hunt SP (1990) Differential expression of immediate early genes in the hippocampus and spinal cord. Neuron 4:603-614.

Young ST, Porrino LJ, Iadarola MJ (1991) Cocaine induces striatal c-Fos-immunoreactive proteins via dopaminergic D1 receptors. Proc Natl Acad Sci USA 88:1291-1295.

Young WS III, Bonner TI, Brann MR (1986) Mesencephalic dopamine neurons regulate the expression of neuropeptide mRNAs in the rat forebrain. Proc Natl Acad Sci USA 83:9827-9831.

Zerial M, Toschi L, Ryseck RP, Schuermann M, Müller R, Bravo R (1989) The product of a novel growth factor activated gene, fos $B$ interacts with JUN proteins enhancing their DNA binding activity. EMBO J 8:805-813. 